\title{
Electroanalysis of urinary L-dopa using tyrosinase immobilized on gold nanoelectrode ensembles
}

\author{
Ana Pinho, Subramanian Viswanathan, Susana Ribeiro, Maria Beatriz Prior Pinto Oliveira, Cristina Delerue-
}

Matos

\begin{abstract}
The performance of an amperometric biosensor constructed by associating tyrosinase (Tyr) enzyme with the advantages of a 3D gold nanoelectrode ensemble (GNEE) is evaluated in a flowinjection analysis (FIA) system for the analysis of Levodopa (Ldopa). GNEEs were fabricated by electroless deposition of the metal within the pores of polycarbonate track-etched membranes. A simple solvent etching procedure based on the solubility of polycarbonate membranes is adopted for the fabrication of the 3D GNEE. Afterwards, enzyme was immobilized onto preformed self-assembled monolayers of cysteamine on the 3D GNEEs (GNEE-Tyr) via cross-linking with glutaraldehyde. The experimental conditions of the FIA

system, such as the detection potential $(-0.200 \mathrm{~V}$ (vs. $\mathrm{Ag} /$

$\mathrm{AgCl})$ ) and flow rates $\left(1.0 \mathrm{~mL} \mathrm{~min}^{-1}\right)$ were optimized.

Analytical responses for L-dopa were obtained in a wide concentration range between $190^{-8} \mathrm{~mol} \mathrm{~L}^{-1}$ and 19 $10^{-2}$ mol L ${ }^{-1}$. The limit of quantification was found to be $1910^{-8} \mathrm{~mol} \mathrm{~L}^{-1}$ with a resultant $\%$ RSD of $7.23 \%(n$ $=5$ ). The limit of detection was found to be $1910^{-9} \mathrm{~mol}$ $\mathrm{L}^{-1} \quad(\mathrm{~S} / \mathrm{N}=3)$. The common interfering compounds namely, glucose $\left(10 \mathrm{mmol} \mathrm{L}^{-1}\right)$, ascorbic acid $\left(10 \mathrm{mmol} \mathrm{L}^{-}\right.$ 1 ), and urea $\left(10 \mathrm{mmol} \mathrm{L}^{-1}\right)$ were studied. The recovery of L-dopa (1 $910^{-7} \mathrm{~mol} \mathrm{~L}^{-1}$ ) from spiked urine samples was found to be $96 \%$. Therefore, the
\end{abstract}

developed method is adequate to be applied in the clinical analysis.

\section{Keywords}

Gold nanoelectrode, Tyrosinase, L-dopa, Electrochemical biosensor

\section{Introduction}

Neurotransmitters are brain chemicals that communicate information throughout the brain and body, relaying signals between neurons. Catecholamine originates from a wide range of neural pathways by employing biogenic amines as neurotransmitters [1]. Levodopa (L-dopa) is an important precursor in the synthesis of dopamine. Dopamine cannot cross the blood-brain barrier and therefore, doesn't have the ability to reach the dopaminergic cells of the brain, while its precursor, L-dopa, can [2]. This is the basic reason for the medication of choice of L-dopa for the treatment of Parkinson's disease, and is mainly metabolized by L-dopa decarboxylase to dopamine, compensating for the defi- ciency of dopamine in the brain. The analysis of neuro- transmitters is of substantial interest for the rapid and early detection of neural disorders and for the quality control of pharmaceuticals. Among several established methods, electrochemical techniques are attractive for the determi- nation of L-dopa because of their high sensitivity as well as their applicability to real-time detection in biological samples [3, 4]. Electrochemical biosensors based on tyrosinase (Tyr) or polyphenol oxidase enzymes are con- sidered as an alternative to the conventional techniques due to their simplified sample treatment, and the possibility of portable, economic, fast, and sensitive analysis [5-7]. Several research groups have investigated Tyr-based bio- sensors for the detection of phenols [8-10]. Tyrosinase- 
catalysed oxidation of tyrosine and other monohydric phenols involves $o$-hydroxylation followed by oxidation of the resulting dihydric phenol to the corresponding $o$-qui- none in a single step without the release of the dihydric phenol intermediate. Usually, for amperometric detection of catechol, with L-dopa having the same base structure, the subsequent electrochemical reduction of $o$-quinone is quantified by measuring the reduction current at low potentials [11]. In recent years, several amperometric bio- sensors based on the inhibition of the activity of Tyr enzymes have been used [12]. A key factor in the con- struction of a biosensor is the need to achieve adequate and effective enzyme immobilization. Some of the common approaches that have been used for the immobilization of Tyr onto various substrates include carbon paste immobi- lization [9, 13, 14], sol-gel immobilization [15], physical adsorption [16] and electrochemical entrapment of the enzyme within a polymer or a composite matrix [17]. However, some of these methods are relatively complex. Therefore, the search for a simple and reliable method to immobilize Tyr is of considerable interest. A wide variety of matrices, including inorganic materials, organic poly- mers, and other commercially available solid supports, have been explored for this purpose [18].

An electrode can be modified by gold nanomaterials in different ways to improve the performance of the biosensor. Gold nanoparticles provide an attractive way for the immo- bilization of biomolecules without affecting their bioactiv- ity. Pingarron et al. [19] recently reported a review on gold nanoparticle-based electrochemical biosensors, in which gold-based enzyme biosensors are summarized. The adsorption of colloidal gold nanoparticles on a chitosan membrane could provide a multilayer gold-nanoparticle assembly providing a suitable microenvironment, which is similar to the native environment of biomolecules. Based on this approach, a disposable biosensor with good detection precision and storage stability was fabricated for the rapid detection of $\mathrm{H}_{2} \mathrm{O}_{2}$ by entrapping horseradish peroxidase in a colloidal gold nanoparticle modified chitosan mem- brane [20, 21]. An electrochemical biosensor can profit by combining gold nanoparticles with inorganic or organic nanomaterials. An example of such a biosensor is a colloidal goldcarbon nanotube (Au-CNT) composite electrode using Teflon as the non-conducting binding material. The con- structed biosensor showed significantly improved responses to $\mathrm{H}_{2} \mathrm{O}_{2}$, and the incorporation of glucose oxidase (GOD) into the new composite matrix allowed the preparation of a mediator-less glucose biosensor with a remarkably higher sensitivity than that from other GOD-CNT bioelectrodes [22].

Metal deposition inside nanoporous membrane tem- plates has proven to be a versatile approach to the fabri- cation of freestanding metallic nanowires $[23,24]$. In general, nanoporous templates are widely available and relatively inexpensive. These templates permit the prepa- ration of materials with a high degree of homogeneity and reproducibility $[25,26]$.

In this study, 3D gold nanoelectrode ensembles (GNEEs) were prepared and characterised for electrochemical detec- tion. The GNEEs were subsequently modified with Tyr and used as the working electrode in an amperometric detector for flow-injection analysis (FIA). The FIA system was applied in the analysis of Ldopa in urine samples.

\section{Materials and methods}

\subsection{Reagents and solutions}

Trifluoroacetic acid $(\mathrm{CF} 3 \mathrm{COOH})$, tin(II) chloride $\left(\mathrm{SnCl}_{2}\right)$, sodium hydrogencarbonate $(\mathrm{NaHCO} 3)$, formaldehyde ( $\mathrm{HCHO})$, methanol $(\mathrm{CH} 3 \mathrm{OH}, \mathrm{MeOH}), \mathrm{L}-d o p a$, glucose, urea and cyste- amine, ammonia (NH3), ammonium hydroxide $(\mathrm{NH} 4 \mathrm{OH}), \operatorname{Tyr}(\mathrm{EC} 1.14 .18 .1)$, bovine serum albumin (BSA), potassium nitrate (KNO3) (Sigma-Aldrich), nitric acid $(\mathrm{HNO} 3)(65 \%)$, silver nitrate (AgNO3) (Carlo Erba), ethanol ( $\mathrm{C} 2 \mathrm{H} 5 \mathrm{OH}, \mathrm{EtOH})$ (Pan- reac), glutaraldehyde (GA), dichloromethane $\left(\mathrm{CH}_{2} \mathrm{Cl} 2\right)$ (Fluka), sodium sulfite (Na2SO3), sodium phosphate monohydrate (Na3 $\left.\mathrm{PO} 4 . \mathrm{H}_{2} \mathrm{O}\right)$, sodium dihydrogenphosphate $\left(\mathrm{NaH}_{2} \mathrm{PO} 4\right)$, potas- sium hexacyanoferrate (II) trihydrate $(\mathrm{K} 4[\mathrm{Fe}(\mathrm{CN}) 6] .3 \mathrm{H} 2 \mathrm{O})$, potassium hexacyanoferrate (III) ( $\mathrm{K} 3[\mathrm{Fe}(\mathrm{CN}) 6]$ ) (Riedel-de Hae n), ascorbic acid, ethyl acetate $\left(\mathrm{CH}_{3} \mathrm{COOCH}_{2} \mathrm{CH}_{3}\right.$, EtOAc), chloroform $\left(\mathrm{CHCl}_{3}\right)$, and carbon tetrachloride (CCl4) (Merck)

were used as received. The sodium gold sulfite solution (100 g Au L 1) $(\mathrm{Na3}[\mathrm{Au}(\mathrm{SO} 3) 2])$ was obtained from Metakem. A urine sample from healthy volunteer was used for recovery studies.

All the electrochemical measurements were performed in 0.1 mol $\mathrm{L}^{-1}$ phosphate buffered saline (PBS, $\mathrm{pH}$ 6.5) at room temperature $\left(25^{\circ} \mathrm{C}\right)$.

All solutions were freshly prepared with Type I deion- ised water (18.0 MX cm) obtained from a Simplicity 185 (Millipore) water purification system.

\subsection{Instrumentation}

An Autolab PGSTAT12 Potentiostat/Galvanostat (EcoChe- mie, the Netherlands) was employed for the electrochemical studies. GPES (version 4.9, EcoChemie, the Netherlands) software was used to perform a variety of electroanalytical techniques.

For the voltammetric analysis the constructed GNEE was used as the working electrode, an $\mathrm{Ag} / \mathrm{AgCl}$ reference electrode (Metrohm), and a platinum counter electrode (Metrohm) were used. These electrodes were inserted in an undivided $25-\mathrm{mL}$ glass cell through a Teflon top. This cell 
top also had purging and blanketing facilities for nitrogen with separate tubes to remove oxygen and to maintain an inert atmosphere in the head-space above the sample solution during the analysis. The purging and blanketing steps were controlled through the GPES software.

The FIA system consisted of a Gilson Minipuls-3 peristaltic pump, a Rheodyne 5020 injection valve $\left(V_{\text {inj }}=201 \mathrm{~L}\right)$, a modified Metrohm 656 wall-jet detection cell, and an Autolab PGSTAT 12 potentiostat/galvanostat. To con- nect the various components of the FIA set-up, Teflon tubing $(d=0.5$ $\mathrm{mm})$ and Teflon end fittings were used. In

the wall-jet cell the working electrode was embedded along one wall of the channel, whereas the reference electrode $(\mathrm{Ag} / \mathrm{AgCl})$ was placed on the opposite side. A platinum counter electrode was used to complete the electrical circuit.

SEM images were obtained using a scanning electron microscope (JEOL, Model FEI Quanta 400FEGESEM/ EDAX PEGASUS 94M). The $\mathrm{pH}$ measurements were made using a $\mathrm{pH}$ meter (Crison, GLP 22).

\subsection{Methods}

A schematic representation of the construction of the bio- sensor is shown in Fig. 1. After their construction both GNEE types (unand modified) were attached to a strip of conducting copper tape. A piece of insulation tape punched with a 6-mm diameter hole was placed onto the etched side of the membrane to ensure that the exposed area of the GNEE was identical for every analysis. The exposed area of the copper tape was also insulated to prevent contact with the electrolyte.

\subsubsection{Preparation of the GNEE}

The gold plating solution was prepared according to a previous published study [24]: dissolution of $3.2014 \mathrm{~g} \mathrm{Na} 2 \mathrm{SO} 3,0.42005$ $\mathrm{g} \mathrm{NaHCO} 3$, and $10 \mathrm{~mL} \mathrm{HCHO}$ in

$180 \mathrm{~mL}$ water. The $\mathrm{pH}$ of this solution was adjusted to 10 and the volume was adjusted to $200 \mathrm{~mL}$ by adding water. Twenty milliliters of this solution was mixed with $0.2 \mathrm{~mL}$ of the $\mathrm{Na} 3 \mathrm{Au}(\mathrm{SO} 3) 2$ solution and the $\mathrm{pH}$ of the resulting solution was again adjusted to 10 .

The used polycarbonate membranes (PC) (Whatman, UK) have a pore size of $50 \mathrm{~nm}$, a pore density of approxi- mately 6000 pores $/ \mathrm{cm}^{2}$, and a thickness of 6-14 $1 \mathrm{~m}$. The membranes were prepared for electroless deposition of gold by immersion in a mixture of $\mathrm{MeOH}$ and water (50:50), containing $\mathrm{SnCl}_{2} \quad\left(0.026 \mathrm{~mol} \mathrm{~L}^{-1}\right)$ and TFA $(0.6 \%, \mathrm{~m} / \mathrm{v})$, for $45 \mathrm{~min}$. The membrane was removed from the $\mathrm{SnCl}_{2}$ /TFA solution, washed with $\mathrm{MeOH}$ for $10 \mathrm{~min}$, activated by immersing it in an ammoniacal $\mathrm{AgNO}_{3}$ solu- tion (obtained by adding a concentrated $\mathrm{NH} 4 \mathrm{OH}$ solution to $50 \mathrm{~mL}$ of a $0.029 \mathrm{~mol} \mathrm{~L}^{-1} \mathrm{AgNO}_{3}$ solution. The solution turned brown when one or two drops of $\mathrm{NH} 3$ were added and became colorless upon further addition of $\mathrm{NH} 3$ ) for $10 \mathrm{~min}$, and thoroughly washed with $\mathrm{MeOH}$ to remove excess $\mathrm{AgNO} 3$. The membrane was then placed, in a ver- tical position, in the gold plating solution for $24 \mathrm{~h}$. The deposited gold on both sides of the membrane was gently removed using Q-Tips wetted with EtOH. The membranes were then immersed in $25 \% \mathrm{HNO}_{3}$ for $12 \mathrm{~h}$ to remove the surface-bound chemicals from the gold plating solution. Finally, the membrane was heated at $150{ }^{\circ} \mathrm{C}$, the glass transition temperature of polycarbonate, for $10 \mathrm{~min}$. This produces a watertight seal between the gold nanoarrays and the polycarbonate pore walls necessary to avoid creeping of the solution into the junction which leads to higher background currents [24]. At this time a gold-filled PC membrane (2D) was also prepared, which was not sub- jected to the etching procedure.

\subsubsection{Etching procedure}

The polycarbonate membrane (PC) was found to be highly soluble in chlorinated organic solvents such as $\mathrm{CCl} 4, \mathrm{CHCl} 3$, and $\mathrm{CH}_{2} \mathrm{Cl}_{2}$ and insoluble in $\mathrm{MeOH}, \mathrm{EtOH}$, and EtOAc. Since the solubility of the $\mathrm{PC}$ membrane in $\mathrm{CH}_{2} \mathrm{Cl}_{2}$ can be regulated by mixing with $\mathrm{EtOH}$, a solvent mixture of $\mathrm{CH}_{2} \mathrm{Cl}_{2}$ and $\mathrm{EtOH}$ $(50: 50, \mathrm{v} / \mathrm{v})$, was chosen as the most suitable etchant to produce the GNEEs, ultimately pro- ducing the GNEEs. Thus the surface of the gold-filled polycarbonate membrane was solvent wiped with a cotton
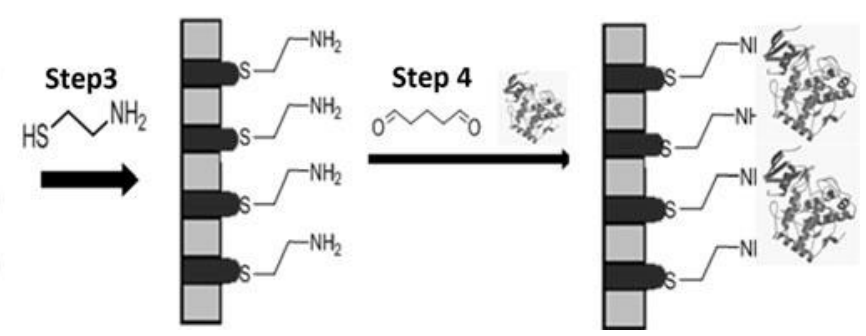

Fig. 1 Schematic representation of the biosensor's (GNEE-Tyr) construction. Step 1 Electroless gold deposition in PC membrane pores. Step 2

Partial etching and exposing gold nanoarrays. Step 3 Self assembled monolayer formation. Step 4 Tyr immobilisation by glutaraldehyde 


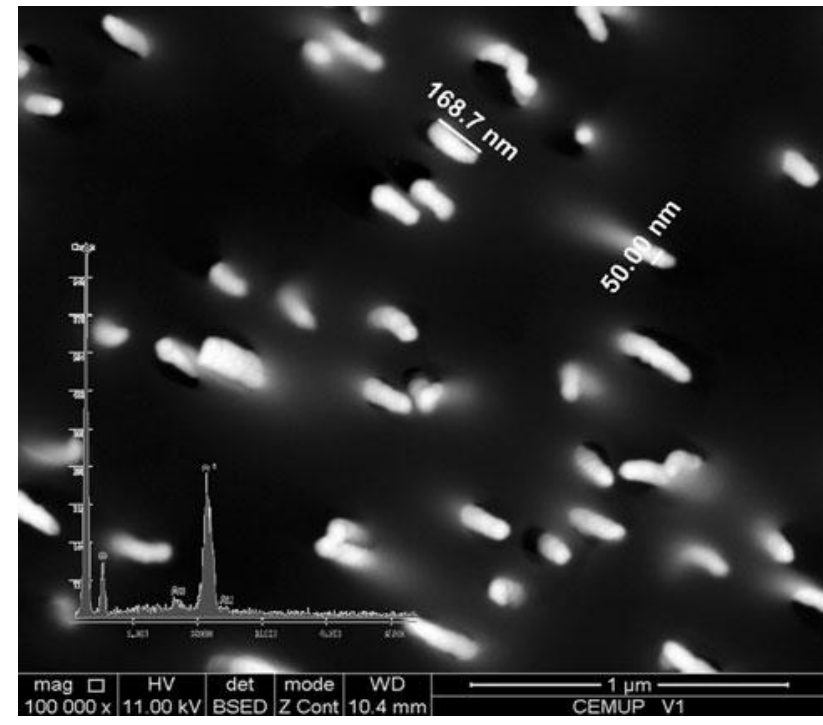

Fig. 2 SEM image of 3D GNEEs. Inset EDX spectrum of goldfilled PC membrane

tip dipped in a 50:50 $\mathrm{CH}_{2} \mathrm{Cl}_{2} / \mathrm{EtOH}$ mixture, immediately followed by a dry wipe of the surface with a dry cotton tip.

\subsubsection{Enzyme immobilization}

The enzyme's immobilization process started with the introduction of amine functionalities on the gold surface by the chemisorption of cysteamine $\left(0.02 \mathrm{~mol} \mathrm{~L}^{-1}, 18 \mathrm{~h}\right)$ using EtOH as solvent. The resulting aminated gold surface was modified by dipping it into a $2 \%$ GA solution for $2 \mathrm{~h}$ at room temperature. An aliquot (50 1L) of Tyr solution

( $1 \mathrm{mg} . \mathrm{mL}^{-1}$ in PBS), was then placed on the surface of the modified gold nanoelectrodes and the sensor was placed at $4{ }^{\circ} \mathrm{C}$ for $24 \mathrm{~h}$. This Tyr-immobilized electrode was then rinsed with a $\mathrm{pH} 7.4$ phosphate buffer to remove any non- immobilized enzyme. Enzyme electrode is then blocked with PBS containing $1 \%$ BSA for $15 \mathrm{~min}$ at $25{ }^{\circ} \mathrm{C}$, to prevent nonspecific adsorption of proteins. Finally enzyme electrode is washed with PBS 5 times and stored at $4{ }^{\circ} \mathrm{C}$ until use.

\subsubsection{Sample preparation}

Urine samples were deproteinized by adding $1 \mathrm{~mol} \mathrm{~L}^{-1}$ perchloric acid; the mixture was vortexed and centrifuged at $2000 \mathrm{rpm}$ for $20 \mathrm{~min}$.

\section{Results and discussion}

Scanning electron microscopy (SEM) was used to analyse the surface of the 3D GNEE. This SEM surface image

(Fig. 2) of the membrane shows gold nanowires with an average diameter of $50 \mathrm{~nm}$ and a length of $180 \pm 20 \mathrm{~nm}$. It also shows the absence of voids on the surface, indicating that this method efficiently produces 3D GNEEs with protruding gold wires. Based on this image, the nanowire's density was found to be 10 nanowires. $1 \mathrm{~m}^{-2}$, which is in accordance with the declared pore density, thus confirming that each template pore was filled with gold. A good elec- tronic conduction was established between the nanoelec- trode ensembles and the copper tape, when the GNEE was connected to the external circuit. Since electrons are capable of penetrating through the finite thickness of the polycar- bonate membrane, small portions of the gold nanowires in the angled tracks are visible. The results of energy dispersive X-ray (EDX) measurements are illustrated in the inset of Fig. 2. The higher gold EDX peak intensity of the etched membrane (3D GNEE), relative to a representative unetched membrane (2D GNEE), demonstrated that the area of each gold-filled pore in the membrane increased. The EDX results evidenced that this method minimized the chemical con-tamination from the gold deposition process during the preparation of the GNEEs.

$$
\text { Cyclic voltammograms (CVs) of } 0.01 \mathrm{~mol} \mathrm{~L}^{-1}
$$
$\mathrm{K} 4[\mathrm{Fe}(\mathrm{CN}) 6]$ and $\mathrm{K} 3[\mathrm{Fe}(\mathrm{CN}) 6]$ in $0.1 \mathrm{~mol} \mathrm{~L}^{-1} \mathrm{KNO} 3$ using 2D and 3D GNEEs showed a higher sensitivity for the 3D GNEE (Fig. 3a). The very low double-layer charging cur- rent indicates the satisfactory sealing treatment between the conducting gold nanowires and the polycarbonate mem- brane. The peak-shaped $\mathrm{CV}$ is due to the close spacing (10

nanowires.1 $\mathrm{m}^{-2}$ ) between the gold-filled pores in the
Fig. 3 a CV of a $0.01 \mathrm{~mol}$ $\mathrm{L}^{-1}[\mathrm{Fe}(\mathrm{CN}) 6]^{4-}$

$/[\mathrm{Fe}(\mathrm{CN}) 6]^{3-}$

solution in $0.1 \mathrm{~mol} \mathrm{~L}^{-1} \mathrm{PBS}$ (pH 7.4) using the 2D GNEE

(dotted line) and the 3D

GNEE (solid line) at 100 $\mathrm{mVs}^{-1}$.

$\mathrm{b}$ CVs of GNEE-Tyr (solid line) and unmodified GNEE (dotted line) in $0.1 \mathrm{~mol} \mathrm{~L}^{-}$ 1 PBS (pH 6.5). Scan rate: $50 \mathrm{mV} / \mathrm{s}$
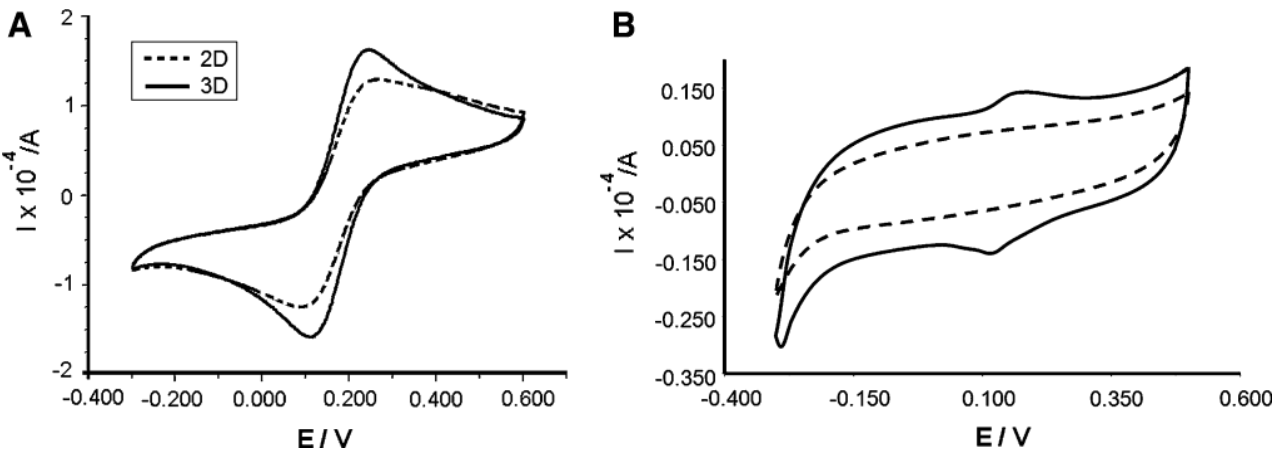
exposed geometric area so that the overlap of individual diffusion layers results in the creation of an apparent planar diffusion layer that extends over the entire GNEEs. Therefore, the GNEEs behave like a macro electrode with a surface area equal to the total surface area of the ensemble. The larger peak current of the 3D GNEE than 2D GNEE evidenced the formation of 3D GNEE. The smaller peak separation values at the 3D GNEE could be ascribed to a faster electron transfer process.

The difference between the CVs of the unmodified GNEE and the GNEE-Tyr illustrates that Tyr has suc- cessfully been immobilized on the GNEE surface (Fig. 3b).

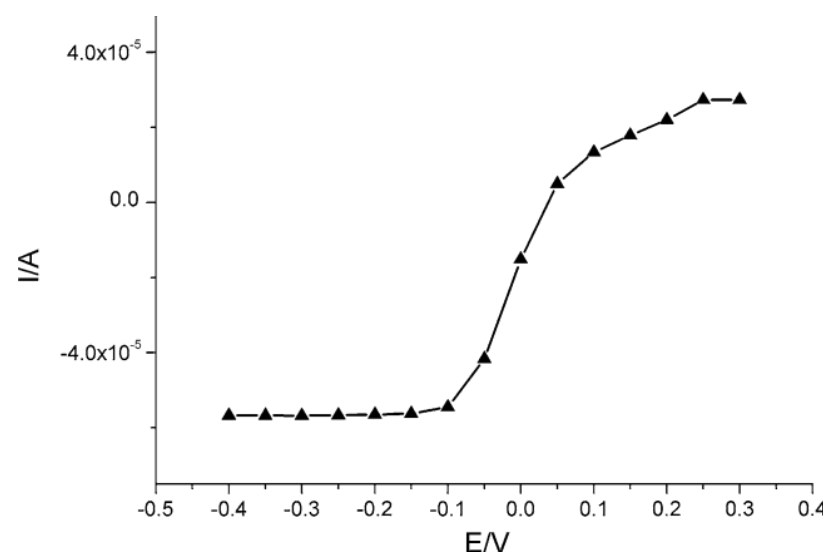

Fig. 4 Effect of the detection potential for the detection of L-dopa in PBS (pH 6.5) at GNEE-Tyr
The reversible redox peak for the GNEE-Tyr centered at E1/2 $0.143 \mathrm{~V}$ corresponds to the $\mathrm{Cu}^{2 ?} / \mathrm{Cu} ?$ redox center of the Tyr molecules.

The FIA system used in the determination of the L-dopa was optimized using the univariate method to improve its analytical performance. The working electrode (GNEE-Tyr) was operated at a desired potential and the transient currents were allowed to decay to a steady-state value. The effects of applied detection potential for L-dopa determination were

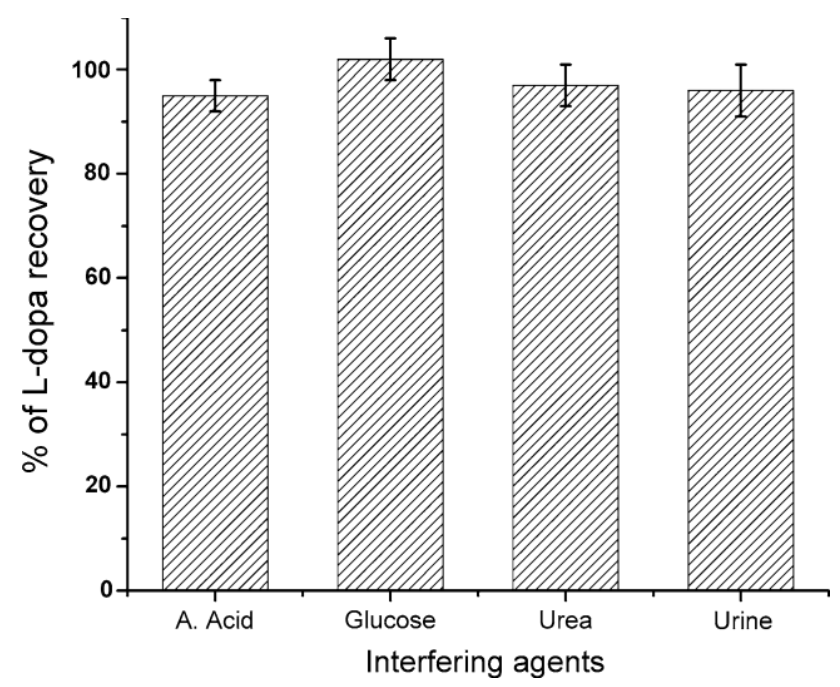

Fig. 6 Recovery studies of $10^{-6} \mathrm{~mol} \mathrm{~L}^{-1}$ L-dopa spiked in inter- ferences $10 \mathrm{mmol} \mathrm{L}^{-1}$ of ascorbic acid, $10 \mathrm{mmol}$ $\mathrm{L}^{-1}$ glucose, $10 \mathrm{mmol} \mathrm{L}^{-1}$ urea and urine samples
Fig. 5 Dose response curve for L-dopa under optimised conditions. Inset $a$ Linear fit of

L-dopa from $10^{-8}$ to $10^{-5} \mathrm{~mol} \mathrm{~L}^{-1}$; Insets $b$, c FIA responses for consecutive $\begin{array}{ll}\text { injections } & \text { of } \\ \text { solutions } & \left(10^{-3}-10^{\text {L-dopa }} 8\right.\end{array}$ $\mathrm{mol} \mathrm{L}^{-1}$ ) in PBS (pH 6.5)

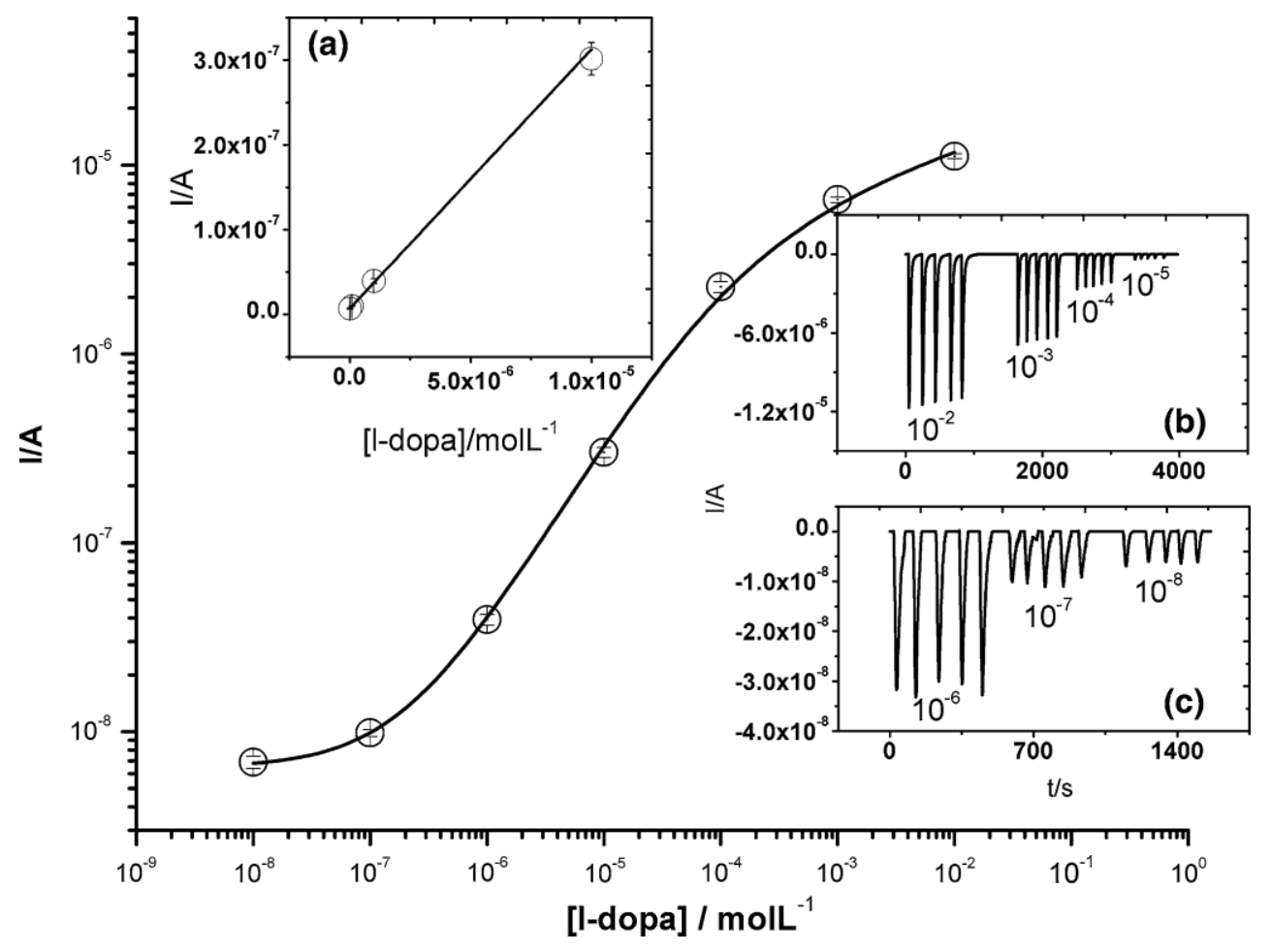


Table 1 Comparison of analytical performance of different electrochemical sensors for L-dopa determination

\begin{tabular}{|c|c|c|c|}
\hline Electrode type & $\begin{array}{l}\text { Range of } \\
\text { determination } \mathrm{mol} \mathrm{L}^{-1}\end{array}$ & $\begin{array}{l}\text { Limit of } \\
\text { detection mol } \\
\mathrm{L}^{-1}\end{array}$ & Ref. \\
\hline GNEE-Tyr & $1910^{-8}-1910^{-3}$ & $1910^{-9}$ & Present paper \\
\hline Modified pencil graphite & $2910^{-5}-1910^{-4}$ & $1.54910^{-6}$ & {$[11]$} \\
\hline $\begin{array}{l}\text { Nickel hexacyanoferrate film } \\
\text { modified gold nanoparticle }\end{array}$ & $0.82910^{-6}-2.5910^{-3}$ & $0.53910^{-6}$ & {$[27]$} \\
\hline Modified pyrolytic graphite electrode & $0.1910^{-6}-150910^{-6}$ & $50910^{-9}$ & [28] \\
\hline GNEE & $2.5910^{-8}-1.5910^{-6}$ & $1.5910^{-8}$ & {$[23]$} \\
\hline
\end{tabular}

studied at selected working potentials, ranging from -400 to ?300 $\mathrm{mV}$. The maximum current response was found at $-0.200 \mathrm{~V}$ and selected as optimum for all subsequent analysis (Fig. 4).

The effect of the flow rate on the L-dopa determination was studied between 0.5 and $1.6 \mathrm{~mL} \mathrm{~min}^{-1}$. The results showed that flow-rates higher than $1 \mathrm{~mL} \mathrm{~min}^{-1}$ were unsuitable because of a large pressure build-up in the system; however, lower flow-rates were associated with lower sampling rates. Therefore, $1 \mathrm{~mL} \mathrm{~min}^{-1}$ was set as the optimal value for further studies.

Calibration graphs were obtained through the analysis of Ldopa standard solutions ranging from $10^{-2}$ to $10^{-8} \mathrm{~mol} \mathrm{~L}-$ 1 , which are within the therapeutic range. The calibration

plot (Fig. 5) demonstrates the relationship between the cur- rent responses against the analyte concentration. The plotted points represent the average of at least five independent replicates per standard. The inset Fig. 5a shows a linear current response for L-dopa between $10^{-5}$ and $10^{-8}$ mol $\mathrm{L}^{-1}$ with $r^{2}=0.996$. The limit of quantification (LOQ) was found to be $1910^{-8} \mathrm{~mol} \mathrm{~L}^{-1}$ with a resultant $\%$ RSD of $7.23(n=5)$.

The limit of detection (LOD) was defined as the lowest concentration of L-dopa that produced a signal, which was three times greater than the standard deviation of the cur- rent in the absence of analyte under identical conditions and corresponded to $1910^{-9} \mathrm{~mol} \mathrm{~L}-1$. The stability of the GNEE-Tyr was studied using the conditions mentioned above. For additions of $10^{-6} \mathrm{~mol} \mathrm{~L}^{-1}$ L-dopa solutions a response time of about $10 \mathrm{~s}$ was observed. The electrodes were stable for more than a month, when stored at $4{ }^{\circ} \mathrm{C}$. The

effect of some possible interfering substances on the GNEE-Tyr biosensor was also studied. Glucose, ascorbic acid, and urea, which are usually present in samples con- taining Ldopa, are known to interfere in electrochemical

measurements at this potential. The presence of $10 \mathrm{mmol} \mathrm{L}^{-1}$ glucose, $10 \mathrm{mmol} \mathrm{L}^{-1}$ ascorbic acid and $10 \mathrm{mmol} \mathrm{L}^{-1}$ urea did not show significant interferences on the analytical spike and recovery of $10^{-6} \mathrm{~mol} \mathrm{~L}^{-1}$ L-dopa

(Fig. 6). Therefore, it can be concluded that the developed GNEE-Tyr had a good selectivity and sensitivity for L-dopa determination. Recovery studies were performed by spiking a known amount of L-dopa in urine. An average recovery of $96 \%$ was found (Fig. 6). Analytical performance of differ- ent electrochemical sensors for L-dopa determination is compared in Table 1.

\section{Conclusions}

In the present study 3D gold GNEEs were constructed for electrochemical measurements. Compared with 2D GNEEs, the 3D GNEEs significantly enhanced the current response in cyclic voltammetry. Tyr was immobilized on the GNEEs surface for the amperometric determination $(E=$ $-0.200 \mathrm{~V}$ vs. $\mathrm{Ag} / \mathrm{AgCl}$ ) of L-dopa in a FIA system. The biosensor showed a good relationship between L-dopa concentration and current in the concentration range from $10^{-2}$ to $10^{-8} \mathrm{~mol} \mathrm{~L}^{-1}$. The advantage of the GNEEs is an enhanced signal-to-background current ratio, leading to lower limits of detection. In this case, an LOD of $1910^{-9} \mathrm{~mol} \mathrm{~L}^{-1}(\mathrm{~S} / \mathrm{N}=3)$ was achieved. There were no significant interferences from glucose, ascorbic acid and urea on mol L ${ }^{-1}$ L-dopa was observed. The developed biosensor was successfully applied to the determination of L-dopa in spiked urine samples. Based on this study, the 3D GNEE-Tyr is a promising sensor for use in the clinical analysis.

\section{References}

1. Stoica L, Lindgren-Sjolander A, Ruzgas T, Gorton L (2004) Anal Chem 76:4690

2. Erdogan H, Tuncagil S, Toppare L (2010) J Macromol Sci A 47:209

3. Robinson DL, Hermans A, Seipel AT, Wightman RM (2008) Chem Rev 108:2554

4. Venton BJ, Wightman RM (2003) Anal Chem 75:414A

5. Lee JM, Xu G-R, Kim BK, Choi HN, Lee W-Y (2011) Electro- analysis 23:962

6. Piao Y, Jin Z, Lee D, Lee HJ, Na HB, Hyeon T, Oh MK, Kim J, Kim HS (2011) Biosens Bioelectron 26:3192 
7. Song W, Li D-W, Li Y-T, Li Y, Long Y-T (2011) Biosens Bioelectron 26:3181

8. Lu L, Zhang L, Zhang X, Huan S, Shen G, Yu R (2010) Anal Chim Acta 665:146

9. Campuzano S, Serra B, Pedrero M, de Villena FJM, Pingarron JM (2003) Anal Chim Acta 494:187

10. Wang L, Ran Q, Tian Y, Ye S, Xu J, Xian Y, Peng R, Jin L (2010) Microchim Acta 171:217

11. Kalachar HCB, Basavanna S, Viswanatha R, Naik YA, Raj DA, Sudhad PN (2011) Electroanalysis 23:1107

12. Sima VH, Patris S, Aydogmus Z, Sarakbi A, Sandulescu R, Kauffmann JM (2011) Talanta 83:980

13. Notsu H, Tatsuma T (2004) J Electroanal Chem 566:379

14. Xue HG, Shen ZQ (2002) Talanta 57:289

15. Zejli H, Hidalgo-Hidalgo de Cisneros JL, Naranjo-Rodriguez I, Liu B, Temsamani KR, Marty JL (2008) Anal Chim Acta 612: 198

16. Marin-Zamora ME, Rojas-Melgarejo F, Garcia-Canovas F, Gar- cia-Ruiz PA (2005) J Chem Technol Biotechnol 80:1356
17. Tembe S, Karve M, Inamdar S, Haram S, Melo J, D'Souza SF (2006) Anal Biochem 349:72

18. Sheldon RA (2007) Adv Synth Catal 349:1289

19. Pingarron JM, Yanez-Sedeno P, Gonzalez-Cortes A (2008) Electrochim Acta 53:5848

20. Liu SQ, Ju HX (2003) Biosens Bioelectron 19:177

21. Liu SQ, Yu JH, Ju HX (2003) J Electroanal Chem 540:61

22. Manso J, Mena ML, Yanez-Sedeno P, Pingarron J (2007) J Electroanal Chem 603:1

23. Viswanathan S, Liao W-C, Huang C-C, Hsu W-L, Ho JA (2007) Talanta 74:229

24. Krishnamoorthy K, Zoski CG (2005) Anal Chem 77:5068

25. Shi HB, Xia T, Nel AE, Yeh JI (2007) Nanomedicine 2:599

26. Shi HB, Yeh JI (2007) Nanomedicine 2:587

27. Prabhu P, Suresh Babu R, Sriman Narayanan S (2011) Sens Actuators B 156:606

28. Hu GZ, Chen L, Guo Y, Wang XL, Shao SJ (2010) Electrochim Acta 55:4711 